\title{
BROADCAST STRUCTURE, TECHNOLOGY, AND THE ABCITT MERGER DECISION
}

\author{
Harvey J. LeviN*
}

Broadcast regulation has from the very outset sought to sustain a diversified and balanced program service through licensing-allocation policies geared to alter industry structure and conduct. Balance refers to the industry's product mix as between national, regional, and local programming and time sales, or as between entertainment, advertising, news, public affairs, and other program types. Diversity refers to the variety of participating program suppliers and sources of talent as well as to the range of viewer choice that results. One crucial dimension of regulatory policy has long been the practice of negotiating back from licensees, in return for valuable access to scarce public spectrum, a public service contribution which they themselves subsidize. All this requires a careful re-examination in the face of impending technological change.

Among the emerging technologies in broadcasting today, none loom larger than pay-TV, community antenna television (CATV), communications satellites, and the new nationwide configurations to which these may each give rise. As these technological developments combine with the nation's important new commitment to public television, prospects have never been brighter for a decisive widening of viewer choice (or a raising of program standards). The common ingredient in all these arrangements is that they could radically transform the whole framework of modern broadcasting, restructuring licensee incentives in ways far more conducive to diversity.

As such, the new technologies pose a fundamental competitive challenge to the nation's present system of advertiser-supported, microwave-interconnected networks of local ground-based stations. Special steps must therefore be taken to guard against allowing serious conflicts of interest to retard their further development and speedy integration into the ongoing structure. This is all the more necessary because regulatory authorities are themselves wedded to concepts which the new technologies are likely to obsolesce.

This paper will focus on only half of the problem-the relation between vertical

- Professor of Economics, Hofstra University. Author, Brondcast Regulation and Joint Ownership of Medis (I960).

The author has written widely on communications economics and regulation, and has served as consultant to a number of foundations, research organizations, and government agencies. He is indebted to the Antitrust Division and the Federal Communications Commission for speedy access to the full record of the ABC-ITT merger case, and for early exposure to the major issues in Commissioner Nicholas Johnson's provocative dissent. Special thanks are due also to Merton J. Peck of Yale for gencral comments on the final argument and to Oliver E. Williamson of the Wharton School for suggestions at the outset. However, the views expressed here are not necessarily shared by any of these individuals or organizations. 
broadcast structure and major procompetitive innovation. The question raised here is whether the innovative incentives and capabilities of our major equipment manufacturers will be strengthened or subverted by a close association with TV broadcast networks and communications common carriers. The second half of the problem-the FCC's longstanding presumption that industry wherewithal must somehow be protected if viewer choice is to be widened significantly-is mentioned only in passing. However, unless the potential restraints inherent in both these factors are analyzed and aired far more fully than hitherto, the vision in question may never materialize.

Within this context, the article will first examine the broad rationale of pay-TV, CATV, public television, and a number of related technological configurations. It will then consider the bearing on their speedy development of greater vertical association among hardware, common carrier, and TV network entities with special reference to the ABC-IT'T merger decision. In keeping with this format, the opening section takes another look at certain procompetitive possibilities recently reviewed by President Johnson's Task Force on Communications Policy, ${ }^{1}$ while the second section deals with issues that the Task Force deemed to need further investigation. ${ }^{2}$

\section{I}

\section{Towards a Postrtive Program to Widen Viewer Choice}

To understand the determinants of viewer choice we must first identify the broadcast industry's basic economic and regulatory framework.

Television's economic structure includes hardware companies, that make the sets; set owners, who view the programs and buy the products advertised thereon; stations, which broadcast or "clear" the programs supplied by national or specialized network companies, by independent program producers, or by the station itself; national, regional, and local advertisers, who sponsor entire programs and buy time for the interspersed commercial messages from the networks for clearances on chains of stations, or from the national spot representatives (for reaching certain specified markets only), and who ultimately support all other components. Finally, three national network companies integrate all but fifty of almost 700 commercial TV stations into nationwide systems, selling the time of affliated stations to network advertisers, supplying commercial and sustaining public service programs to the affliates, and leasing from the American Telephone \& Telegraph Company (AT\&T) the coaxial cable and microwave facilities which link together the chains of stations that advertisers order.

As for regulation, the Federal Communications Commission allocates spectrum to the several broadcast services and enfranchises all stations according to a variety

\footnotetext{
${ }^{1}$ President's Task Force on Communications Policy, Final Report ch. 7 (ig68) [hereinafter cited as TASK Force REPORT].

II. at $37-42$.
} 
of administrative criteria geared to diversify program choice on a wide geographic basis, consistent with signal clarity. In the absence of public utility rate control, broadcast licensing and allocation purport to free the licensed station owner from constraints by the industry's two most powerful (and unlicensed) components-the networks and national advertisers-leaving him hopefully better able to choose among competing program suppliers and advertisers in discharging his public service responsibilities.

One major goal is to widen choice, first, by diversifying the licensee's programming and financial sources and, second, by inducing him to subsidize internally cultural-informational-educational matter for admittedly minority audiences, in return for access to valuable spectrum, often under protected market conditions. In addition, the Commission purports to maximize the number of different signals receivable and of local stations located in any and all-sized markets. In so doing, conflicts must be resolved, such as those involving more national and regional services versus more local community stations (a longstanding FCC priority); speedier entry of commercial TV stations in the choice VHF band (via narrower geographic spacing) versus the protection and nurturing of a more diversified multistation UHF structure, with a larger number of noncommercial public television stations.

Within this context, public television can be considered a major alternative to the FCC's current licensing-allocation practice in the commercial sphere, but not the only alternative. Other organizational options and innovations include paytelevision, community antenna television (CATV), and new network entry via lower (satellite) interconnection charges and improved techniques to equalize the service range and signal quality of VHF and UHF transmissions. ${ }^{3}$ Under any positive program built on these or related components, new technology may potentially operate to (a) diversify the financing of TV programs; (b) provide the physical basis for more program options, in more markets; and $(c)$ facilitate the entry of more national program suppliers, both commercial and noncommercial. In the aggregate, viewer choice would be widened and minority tastes satisfied more effectively, in more markets, than under the present economic structure and framework of incentives.

\section{A. Pay-Television}

By "pay-TV," reference is made to TV program transmissions to viewers whose sets are equipped with special attachments which record the programs received

\footnotetext{
${ }^{8}$ Licenses to operate stations in the UHF and VHF television bands have long conferred disparate carning potentialities. These have in large part been due to the limited number of sets equipped to receive UHF signals, the UHF operator's further reluctance to invest in adequate antenna towers and high-powered transmitters, and the continued absence of a convenient UHF tuncr. Although most observers deny the existence of any inherent physical superiority of VHF transmission, these technical differences in available equipment still operate to the economic detriment of UHF stations. See id. at $24-25$.
} 
and fix the charges. Whether transmitting over-the-air, or over wire grids, the payTV operator utilizes a "scrambled" visual signal intelligible only after "decoding" for subscribers who pay periodic billing charges or who insert coins or tokens directly into a pay-box for subsequent collection. Metering and billing may be centralized or decentralized, but nonsubscribers are in any case excluded. ${ }^{4}$

Pay-TV has certain theoretical attractions in any system based on advertisersupported national networks. This is true even if one accepts recent studies (which predict no striking changes from present "free" TV programming)" as more indicative of what a full-blown subscriber system would look like than they probably are. Pay-TV would at least provide a more direct and persuasive index of the set owners' program preferences than those "rating services" which now estimate the audiences of specific TV programs for advertising purposes, irrespective of the sums different viewers would be willing to pay directly rather than do without these (or other) programs. ${ }^{6}$ Even if pay programming turned out to be identical to present advertiser-supported programming, the possibility that somehow "advertiser control" had deprived viewers of truly preferred program options would be answered once and for all. Towards this end, however, one must presumably have totally separate, independent, and competing pay-TV and conventional TV systems, not pay-TV as a mere supplementary device subject to restrictions as to permissible time of day, number of broadcast hours, types of programs, market size, and so forth. ${ }^{7}$

The current studies do in any event reveal at least some diversification of entertainment programming.. And even the token educational-cultural service subscribers choose to buy is by no means insignificant if one (a) extrapolates it to a full nationwide system; (b) considers the prior twenty-year period during which the conventional system developed; or $(c)$ weighs what the pay-TV companies could have done had they incurred comparable losses. ${ }^{9}$ Nor, finally, is current pay programming conducted under experimental conditions necessarily indicative of what

\footnotetext{
"Subseription TV normally does not include those few cases where, without "scrambling," the licensee solicits voluntary contributions from his viewers.

'For a look at several representative studies by a well-known opponent of pay-TV, see Blank, The Quest for Quantity and Diversity in Television Programming, 56 Am. Econ. Rev. Papers \& Proc. $448,451-54$ (I966).

'Broadcast rating services have long been criticized as inaccurate indexes of consumers' program preferences. See House Comm. ON Interstate and Foreign Commerce, Evaluation of Stamistical Methods Used in Obtaining Broadcast Ratings, H.R. Rep. No. 193, 87th Cong., ist Sess. 7-8, 12, 20-36, 59-87, I18-38 (г96r).

7 The American Civil Liberties Union and Americans for Democratic Action have indorsed fully independent and competitive systems to stimulate and diversify the programming of both. See Amendment of Part 73 of the Commission's Rules and Regulations (Radio Broadcast Services) to Provide for Subscription Television Service (Fourth Report and Order), I5 F.C.C.2d 466, paras. r89, 254-57, 278 (1968) [hereinafter cited as Subscription Television Report]. The latter ostensibly seeks even further insurance against advertiser control through the imposition of common carrier restraints on a nationwide pay-TV/CATY grid. Id. paras. 254-57.

${ }^{8}$ Id. paras. 60-68.

Id. paras. $46,57,69$.
} 
a mature pay-TV structure would look like after program suppliers had fully adjusted on the supply side. ${ }^{10}$

More important, pay-TV might help activate the underutilized UHF band and, through that, implement the Commission's goals vis-à-vis maximum area coverage, multiple service areas, local community service, and nonprofit public service. Activation of the UHF band and of ETV assignments generally, in part through pay-TV, would on certain assumptions go far to widen viewer choice in any and all markets. ${ }^{11}$

\section{B. A Role for CATV}

The safeguards for fairness, accuracy, balance, and diversity which current licensing policies purport to provide, then, can clearly be provided by other structural safeguards. Public television and pay-TV are only two; the rise of community antenna television is still another.

By "CATV," reference is made to a master antenna usually set on a high hill, peak, or building top which permits the CATV operator to pick up signals of conventional TV stations in adjacent areas. The CATV facility then amplifies these signals and transmits them by cable or microwave relay, ultimately distributing them over wire droplines to subscribers, who pay initial installation charges and, thereafter, flat monthly charges unrelated to the particular programs viewed. Currently projected CATV systems can carry as many as twenty signals, about half the theoretical maximum and over twice the present number of conventional TV channels assigned even to the largest markets. At the outset, CATV served only those smaller markets which, due to topography or limited economic support, were deprived of three-network service from nearby local stations. Increasingly, however, CATV has imported TV programs over long distances and could, if permitted, widen the range of viewer choice in the large urban markets as well.

Representative policy issues are whether CATV operators should be $(a)$ required to pay for the programs they pick off the air; $(b)$ permitted (or required) to produce their own programs besides; $(c)$ under any conditions permitted to sell time to advertisers in addition to charging their subscribers for installation and monthly service; or $(d)$ permitted to interconnect into long-distance regional or national grids to provide a competitive alternative to national network television. Heretofore, the FCC has tried to strike a balance between using CATV positively to introduce a diverse national service and full network balance into the smaller TV markets, and restraining CATV in all-sized markets so as to safeguard those

\footnotetext{
${ }^{10}$ Comments of H. Barnett \& P. Steiner, The Economics of Broadcasting and Advertising, 56 AM. Econ. Rev. Papers \& Proc. 467 et seq. (I966).

${ }^{11}$ These potential contributions to diversity have generally been neglected in the theoretical discussion. But see Subscription Television Report, supra note 7, paras. 70-82, 195-96 (UHF), 349-55 (ETV). See also Joint Comments of Zenith Radio Corp. and Teco, Inc., at 23-36, 40, 58-59, 63, in Subscription Television Report, supra, No. 1 I279 (F.C.C., filed Mar. Io, 1965).
} 
broadcast profits which still help subsidize the local live program service. ${ }^{12}$ So far, the second option has tended to prevail. However, CATV's continued development, and new FCC rules, may now better reconcile the local service and diversity goals with one another. ${ }^{13}$

Although CATV's dramatic growth has been said to reflect the public's desire for more of the current TV program fare, ${ }^{14}$ its effects on diversity are rather complex. Scheduling at different hours can widen aggregate choice even when identical programs are provided. Choice is also widened where CATV imports a full range of network service, in the face of difficult terrain, into markets with few, if any, stations. (This is probably still its most obvious contribution.) On the other hand, local service represents a diversifying element in its own right in markets serviced by the national networks.

Hence the Commission's present policy of "mild constraint" can be said to promote diversity by safeguarding a local service that would otherwise not survive and by facilitating new UHF entry. ${ }^{15}$ But this may really not be the most judicious way to reconcile local station viability with diversity-via-CATV growth. Ideally, no such determination can be made without careful prior review of $(a)$ the case for direct UHF subsidies; $(b)$ the use of combined CATV/pay-TV arrangements to permit viewers to choose directly between national and local service; ${ }^{16}(c)$ the revamping of the TV Allocation Table to increase the number of three-station

${ }^{13}$ See Fisher, Community Antenna Television Systems and the Regulation of Television Broadcasting, 56 Ax. Econ. Rev. Papers \& Proc. 320, 322-23, 328-29 (1966); Note, The Wire Mire: The FCC and CATV, 79 HARv. L. REv. 366, 385-89 (I965).

Fisher has estimated CATV's impact on local stations as "substantial," and potentially injurious to their survival, especially in the smaller markets. See Fisher et al., Community Antenna Television Systems and Local Television Station Audience, 80 Q.J. EcoN. 227, 250 (I966.) But these estimates have been criticized as somewhat exaggerated. See M. SEIDEN, AN Economic ANalysis of Community antenna Television Systems and the Television Broadcasting Industry 67-8I (current impact), 89-90 (UHF entry) (1965). See also Comments of Columbia Broadcasting System at I7, 18-29, Amendments of Parts 2I, 74, and $9 \mathrm{I}$ to Adopt Rules and Regulations Relating to the Distribution of Television Broadcast Signals by CATV Systems, No. I597I (F.C.C., filed July 22, I965).

${ }^{13}$ See Amendment of Part 74, Subpart $\mathrm{K}$, of the Commission's Rules and Regulations Relative to Community Antenna Television Systems (Notice of Proposed Rule Making and Notice of Inquiry), I5 F.C.C.2d 4I7, paras. I5-I6 (1968) [hereinafter cited as Proposed CATV Rules].

14 Blank, supra note 5 , at $455-56$.

${ }^{15}$ Fisher, Community Antenna Television Systems and the Regulation of Television Broadcasting, 56 Am. Econ. Rev. Papers \& Proc. 320, 327-29 (I966). The policy of mild restraint is twofold. On request, CATV stations must carry the signals of all local stations in their market but may not do so on the same day. Nor without prior Commission approval may they bring distant signals into the top roo markets, if not already receivable there off-the-air. See Amendment of Subpart L, Part 9I, to Adopt Rules and Regulations to Govern the Grant of Authorizations in the Business Radio Service for Microwave Stations to Relay Television Signals to Community Antenna Systems (Second Report and Order), 2 F.C.C.2d 725, paras. 49, I4I ( 1966 ) [hereinafter cited as CATV Report]. A proposed modification of the latter constraint would require all CATV operators to secure prior retransmission consent of the originating stations, but eliminate the hearing requirement. Proposed CATV Rules, stipra note 13 , paras. $33-35,38,41-44$. In all other markets, hearings would continue on an ad hoc basis to reach comparable determinations. Id. paras. 55-59.

${ }^{10}$ Note, The Wire Mire, supra note 12, at 385-87. 
markets with full network coverage; ${ }^{17}$ and $(d)$ the Commission's newest conception of CATV as a program-originating, diversified, and local-oriented multi-channel service in the major markets.

In this latter regard, CATV would originate some of its own programs, possibly subject to explicit safeguards of fairness, equal time, sponsor identification, diversified ownership, and so forth, with special channels for nonprofit public service, municipal government, business, industry, and conventional stations. ${ }^{18}$ According to the Commission,

. . CATV is rapidly evolving from its original role as a small, five-channel, reception service bringing television ... signals to areas which lack broadcast service or ... the full services of the three national networks. ... It now appears that cable technology may be on the verge of expanding system capacity to 20 or more channels, and that a variety of new services to the public are envisioned. ... [T] he CATV industry generally is placing increased emphasis on program origination, both of a local public service nature and of the entertainment type, and on the provision of other services to the public....

[In authorizing a test of CATV program origination] the Commission stated ( 13 F.C.C.2d $478,505-06$ ):

"CATV program origination offers promise as a means for increasing the number of local outlets for community self-expression and for augmenting the public's choice of programs and types of service, without use of spectrum. ... The CATV system is not handicapped by limited channel capacity, having 12 channels in comparison to the one channel of the individual broadcaster, and thus has the technical Alexibility to provide different types of programs or services on some channels without affecting the service simultaneously provided on other(s).... The CATV operator has more flexibility to present programming of minority interest on some channels. . .."19

Along somewhat different but clearly related lines, the Mayor's Task Force on CATV and Telecommunications in New York City conceives of a citywide system, eleven of whose eighteen channels are used to carry signals of the eleven local TV stations, three other channels being reserved for municipal use at no cost, with the remaining four being used for program originations by the CATV companies themselves. Each CATV operator would hold two of these latter channels, using one for public service programs, the other for general programs, and making both available for leasing by outside program suppliers on request. ${ }^{20}$

Should this new conception prevail, viewers in the larger markets would eventually benefit as much from CATV penetration as those in the small markets

\footnotetext{
17 This could be done by authorizing broadeasters in the smaller markets to widen their service areas in a prearranged way and by permitting UHF broadcasters to use translators for this purpose. SEIDEN, stipra note I2, at 89-90; $c f$. Fisher, supra note 15, at 327-29.

${ }^{18}$ Proposed CATV Rules, supra note 13, paras. II-25.

${ }^{10} I d$. paras. $4-5$.

${ }^{20}$ Mayor's Advisory Task Force on CaTV and Telecommunications, Report on Cable Television and Cable Telecomanunications in New YoRk City 55-60 (ig68) [hercinafter cited as Repont on Cable Thleviston].
} 
now do. However, one final problem relates to the program costs which unfavorable copyright legislation might impose. ${ }^{21}$ Would copyright liability induce the CATV companies to produce more of their own programs locally-especially since the incremental cost of CATV transmissions is so low? Or will multiple local overthe-air services in the top markets offset superior CATV signal quality as a factor in subscriber demand? CATV's future status and effective contribution to diversity will to some degree depend on answers to questions like these.

\section{The Place of Public Broadcasting}

Some observers consider nonprofit public television mainly an interim measure, useful until new technology and perhaps pay-TV financing provide greater diversity. Those who take this position discount any notion of "raising" or "diversifying" general tastes, and see the problem as merely one of satisfying as many existing taste groups as technically and economically possible.

But the goal of public television is more properly viewed as widening the choice for (and tastes of) the general audience, not the elite. In that sense, there is a real question as to whether even pay-TV combined with CATV systems under the proposed new FCC rules can do the job any more than can narrower geographic spacing of VHF stations (to facilitate more entry into that choice band) or improved UHF hardware to fill out the FCC's whole vision of a multi-station structure. We would have to go some very long way in multiplying the number of commercial outlets before profit-maximizing stations would normally be motivated to turn to the minority taste groups-far further, at least, than would be necessary to reduce the industry's economic rents. ${ }^{22}$

Depending on subscriber demand, moreover, pay-TV systems might not generate sufficient support for a generally available public service/public affairs option. The

\footnotetext{
${ }^{31}$ The Supreme Court has observed that "CATV operators, like viewers and unlike broadcasters, do not perform the programs that they receive and carry." Fortnightly Corp. v. United Artists Television, Inc., 392 U.S. 390,401 (I968). Hence there is at this time no copyright liability for the programs CATV companies import-under the factual conditions of Fortnightly, at least. However, Congress could specify copyright liability. Id. at 40r-02. Until recently it was not clear that CATV systems would not be liable where they originate their own programs in part, or bring in signals over microwave rather than cable links from remote points. See Broadcasting, June 24, 1968, at 19-22, 86 . The FCC has since issued an order allowing all CATV operators to originate programming and requiring those systems having at least 3500 subscribers to do so after January $I_{3}$ 197x. See Proposed CATV Rules (First Report and Order), stipra note I3, I7 P \& F Radio REg. 2d I570 (Oct. 24, 1969).

${ }^{22}$ Additional TV stations may not necessarily produce significant increases in program diversity. See Steiner, Program Patterns and Preferences and the Workability of Competition in Radio Broadcasting, 66 Q.J. Econ. 194-207 (1952); Rothenberg, Consumer Sovereignty and the Economics of Television Programming, Studies in Public Communication (No. 4), Autumn 1962, at 45, 47-49. Recent empirical study tends to support these a priori conclusions. Herman W. Land Associates, Inc., Televiston and the Wired City: A Study of the Implications of a Change in the Mode of Transmission ch. 2 (I968). However, these analyses take as given the number of national network companies. New network entry could alter the relation between numbers of stations and the range of program choice. Nonetheless, the introduction of public television would do so in a far more dramatic fashion. Id. at 44-46, 52-56.
} 
existence of merit wants, and the case for keeping some program options available though few will choose to use them, become particularly germane at this point. And here public television is obviously the crucial alternative to Commission-induced internal subsidization of comparable program fare. Finally (and setting the issue of pay-TV to one side), the costs of building and operating a nationwide system of public television must be compared with those of the government programs to develop and institute the new wire, satellite, and related technologies needed to enable the present commercial broadcast system to do the job without public television.

The commercial broadcaster might on several counts benefit from a policy directed toward putting ETV stations in his market. At some point, granted, a greater number of commercial outlets will widen program choice. But depending on the relative size of the potential audiences for specialized and general program types, it could, as suggested, take a very long time for this to happen. ${ }^{23}$ Therefore, the commercial licensee might ultimately confront the worst of both worlds: excessive interstation competition but no greater diversity and balance to assuage his sharpest critics.

A sounder approach for industry and regulator alike would be to encourage a modest increase in the number of commercial stations together with more (and more viable) nonprofit educational stations. Here program choice would be widened not by increased numbers alone but by institutional competition. ${ }^{24}$ Diversity, including a balanced treatment of controversy, could thus be furthered-more directly for the FCC and more cheaply and efficiently for the industry. This approach would also provide the broadcaster with insurance against any serious move to put sharper teeth into present licensing practice.

Any attempt to strengthen the role of public television requires us to reconcile the dual requirements of public accountability and insulation from political intrusions. Several questions are involved here. What factors must be determinative in choosing between some extension of the normal period for general federal appropriations and infusing greater accountability into a dedicated tax approach? What package of tax options would best meet the requirements of equity, stability, economic efficiency, and political acceptability? What role if any might remain for (a) earmarked satellite cost-savings, (b) reduced-rate interconnection for public broadcast networks, or $(c)$ an intermediary Broadcast Trust Fund as a conduit connecting the tax sources and the public broadcast entities?

\footnotetext{
${ }^{28}$ Herman W. LAND Associates, supra note 22, at 44-46, 52-56.

21 . The contrasting role of educational and commercial television was restated vividly by the Ford Foundation in Comments, vol. $x$, at $I-6$, Establishment of Domestic Noncommon Carrier Communication Satellite Facilities by Nongovernmental Entities, No. I6495 (F.C.C., filed Aug. 1, 1966); Reply Comments of the Ford Foundation, vol. r, at 66-98, No. 16495 (F.C.C., filed Dec. 12, 1966). See also Goldin, Commercial Television, a supplementary paper in Carnegre Commisston on Educational Television, Public Televiston-A Program for Action 227-34 (1967). For a discussion of public television funding, see Goldin, Financing Public Broadcasting, in this symposium, p. 650.
} 
Three final technical possibilities now merit brief mention: a domestic satellite relay system, a nationwide CATV grid, and a television satellite for direct broadcasting. Each conception ties in nicely with the above discussion but must be distinguished from it on at least one count: the new configurations would mean a radical modification of the present ground-based, microwave/cable-interconnected local broadcast system.

\section{Relay or Distribution Satellites}

By reducing the cost of long-distance TV program distribution, so-called relay satellites might facilitate new entry by commercial network companies, as well as an expanded public TV service. ${ }^{25}$ Until the new networks enter, a rising number of competing commercial stations would alone do little to widen program choice. And even with new network entry, the widening of choice would be modest compared to the potential impact of public television. Nevertheless, any procompetitive regulatory program must consider not only the possibility of new networks but also the barriers long posed by high interconnection charges.

During the early demise of UHF stations fifteen years ago, higher interconnection costs and "UHF troubles" were both blamed for DuMont's withdrawal from network television. ${ }^{26}$ At that time, AT\&T's practice was to impose high flat charges irrespective of effective channel utilization, whereas special rates for occasional users would have helped ease the resultant entry barriers. ${ }^{27}$ Under conditions of long-run diminishing costs, differential interconnection rates may justifiably be charged different classes of users, with differing elasticities of demand, provided only that the rates exceed incremental costs. At present satellites are as suitable as microwave or cable links for such occasional pricing at well below average costs. $^{28}$

Will lower interconnection charges facilitate the entry of new networks or specialized occasional users? This clearly depends on the magnitude of the charges relative to expected broadcast revenues for the stations involved. New entry is more likely where $(a)$ the rate structure offers special charges to part-time or specialized users, and (b) UHF coverage in the major U.S. markets approaches that of their VHF stations.

Without prejudging the issue here, it will suffice to note first that the threat of private domestic satellites has already jarred loose competitive counterproposals from

\footnotetext{
${ }^{25}$ See text accompanying notes $67-72$ infra.

${ }^{20}$ See House Comm. on Interstate and Foreign Commerce, Network Broadcasting, H.R. Rep. No. 1297, 85th Cong., 2d Sess. I98-204, 541-46, 552 (1958).

37 This clearly follows from the far higher hourly rates that would result when any network or network grouping ordered less than eight hours a day of continuous service. See Dirlam \& Kahn, The Merits of Reserving the Cost-Savings from Domestic Communications Satellites for Support of Educational Television, 77 YALE L.J. 494, 502, 5II-I3 (I968).

${ }^{28}$ Id. at 513 .
} 
the carriers. ${ }^{29}$ The Commission's hand should henceforth be strengthened increasingly for negotiating the kind of rate structure just described, whatever its willingness to do so. As for the "UHF problem," prospects for viable UHF stations look brightest in one- and two-station markets and poorest in markets with four or more stations (where they will most likely lack a network tie). The question is whether new programming can build larger UHF audiences over time in the leading markets. Considerable risk capital will be needed, but any significant cost reduction in tying together a new grouping of albeit initially marginal stations will certainly help. It would, for example, release revenues for program development which contributes further to audience circulation, time sales, and the value of adjacencies, and hence to monies for still better programming, ad infinitum. At best a "chicken-or-egg" phenomenon, the argument that lower interconnection charges will facilitate new entry must be viewed in the context of time. ${ }^{30}$

\section{Wired-City Television and a Nationwide CATV Grid}

The development of low-cost techniques to interconnect local CATV systems into regional or national grids could facilitate the entry of still other companies to produce and distribute TV programming. Combined with pay-TV, these grids might provide the physical basis for a national TV system competitive with current advertiser-supported off-air networking. ${ }^{31}$ Once again, the entry of new national program suppliers could alter the present relation between the number of stations in the market and the range of program choice that results.

A fully-installed CATV grid would not only provide subscribers with a large number of channels (as many as twenty) but would facilitate, at little extra cost, the delivery of additional sources of programming. Abstracting from intercity interconnection costs, Barnett and Greenberg estimate the investment cost of wiring a city of roo,000 at $\$ 6$ million, with subscribers paying fifteen to twenty per cent of this annually. At annual rental charges of five per cent of investment cost for program distributors to deliver their signals, annual distribution costs would be $\$ 300,000$, or $\$ 15,000$ per channel, for a fully-utilized twenty-channel system. For

${ }^{29}$ See text accompanying notes $67-72$ infra. Of relevance here also is AT\&T's offer to reduce ETV rates for underutilized daytime hours, an offer at least consistent with the company's explicit strategy to forestall the establishment of private domestic satellites. See Hearings on S. II60 Before the Stbbcomm. on Communications of the Senate Comm. on Commerce, goth Cong., ist Sess. 4II-I5 (1967).

${ }^{30}$ On the interrelations over time of program inputs, UHF set penetration, and UHF revenues a decade ago, see Levin, Economic Structure and the Regulation of Television, 72 Q.J. EcoN. 424, 431-34 (1958). This aspect clearly contrasts with the dubious possibility that lower interconnection costs will in the first instance induce the existing networks to supply more programming to more familics, by affiliating with more stations and otherwise achieving more program clearances. Dirlam and Kahn correctly discount the likelihood and magnitude of these latter potential effects and thus predict a swelling of economic rents at the local level. Dirlam \& Kahn, supra note 27, at 504-ro.

${ }^{31}$ Proposed CATV Rules, supra note 13, para. 9; Subscription Television Report, stupra note 7, paras. 356-60, 363-70, 378-84; RepoRT ON CABLE TELEvision, stipra note 20, at 62-64. See also Barnett \& Greenberg, Regulating CATV Systems: An Analysis of FCC Policy and an Alternative, in this symposium, p. 562 . 
a ten hour broadcast day this means only five dollars per broadcast hour (or ten dollars per hour where only half capacity is used). ${ }^{32}$ This contrasts with the costs that could conceivably confront a new TV station entrant today: \$I million to $\$ 2$ million for initial capital expenditures and another $\$ 500,000$ to $\$ 1$ million in annual operating expenses.

Because the initial costs of wiring a city for television will vary with its population density, however, sparse fringe areas would presumably be uneconomic to cover in this way. ${ }^{33}$ However viewed, therefore, some supplementary local broadcast stations would continue to be necessary unless, perhaps, direct broadcasting from satellites to rural homes should become feasible.

In regard to the wired segment of any microwave- or satellite-interconnected CATV grid, the elimination of local stations and resultant release of valuable spectrum raise exciting new financing possibilities. Just as the value of broadcast spectrum released by narrower VHF spacing, or more tightly packed UHF allocations, could facilitate the emergence of new technical configurations so, too, the release of far more spectrum in the instant case could ease the conversion to wire television and a nationwide interconnected grid. $^{34}$ The obstacle is more one of present administrative practice than of the brute cost of wholesale conversion.

The wire TV conception might in any case have to be instituted all at once, since any more gradual transition from the current CATV systems would encounter at least three serious obstacles. First, the CATV operations that are now so profitable might be far less so if required to pay for the broadcast programs they transmit. Second, it is not yet clear how attractive CATV will be in markets with four or more local broadcast stations (and a full range of network service). Finally, as noted earlier, the FCC has itself sought to curb CATV growth and would presumably restrict any related development which threatened potential local UHF service.

In the event of extensive local CATV program origination, on the other hand, the Commission might be more willing to permit CATV to grow without restraint. ${ }^{35}$

\footnotetext{
${ }^{39}$ Barnett \& Greenberg, A Proposal for Wired City Television, in Communications and the Future: A Sympositm, I 968 WASH. U.L.Q. I, 20-22.

${ }^{83}$ The level of monthly cost per subscriber of wiring a city of roo,o0o has been estimated as low as \$1.50. Id. at I6-x9. For a small community (population 25,000) with 500 miles of streets and fifty subscribers per mile, Almarin Phillips offers crude estimates of investment per subscriber of $\$ 102$ and level monthly costs of $\$ 3$. A Phillips, Television and New Communications Technologies, at I3-I5 (unpublished paper presented at the AT\&T-Georgetown Univ. Conference on Communications, Summer 1967). As city size and subscriber density rise, investment costs per subscriber might decline to as low as $\$ 29$, and monthly operating costs to less than $\$ \mathrm{I}$, for communities of 250,000 population with 1500 street miles and subscriber density of 150 per mile. Id.

36 The value of broadcast spectrum at the margin to next-best users in land mobile radio or space satellites has not been estimated here but could be considerable. For a short discussion of spectrum valuation see Webbink, The Impact of UHF Promotion: The All-Channel Television Receiver Law, in this symposium, p. $535,553-54$.

${ }^{35}$ According to some observers, the 20-channel grid would simultaneously enhance the chances for local programming, diversity, and service for minority tastes. As such, its appeal to regulatory reformers is easy to understand. See Barnett \& Greenberg, supra note 32, at 12-16, 20-2I, 23-25; Greenberg, Wire Television and the FCC's Second Report and Order on CATV Systems, ro J. Law \& Econ. 181, 185-
} 
The present balance between CATV and broadcast TV might then gradually shift to favor CATV on a national basis. Any likelihood of an all-out conversion would be influenced by the rising marginal value of broadcast spectrum to next-best users and by the rising spectrum congestion which this reflects. Even where proven spectral rents are not collected, the identification, measurement, and divulgence of spectrum costs could at least force the government's hand in planning for a wholesale switch.

A satellite-interconnected CATV grid, or system of wired-city television, requires for its effective development the capabilities of hardware companies with substantial resources and know-how. These firms should ideally be free of large investments in the current ground-based broadcast system, which might of course be jeopardized. Clearly needed also are entities without a big stake in the cablemicrowave links that interconnect off-air television today. Finally, the possibility that a distribution satellite might facilitate new TV network entry underscores the need for hardware or common carrier entities without a stake in the present TV network structure.

\section{Direct Broadcast Satellites}

Looking further into the future, the more remote possibility of satellite-to-home broadcasting offers still another case in point. In regard to program diversity, the direct broadcast satellite may eventually generate more options per megacycle bandwidth than any other broadcast system. It might even do so at lower nonspectrum costs; however, this depends in part on whether the satellite-to-home system must be accommodated in the upper spectral regions ${ }^{36}$ and also on how quickly the needed hardware can be developed and the prohibitive cost of expensive new home receivers and antennas brought down. Once again, the Commission's commitment to local live service could pose a serious near-term impediment. Direct broadcast satellites may well obsolesce local ground-based broadcast stations as well as local CATV. Accordingly, the Commission's longstanding promotion of local service may produce a regulatory roadblock even more onerous than that now confronting the local CATV systems.

One way out would lie in technological development of capabilities to beam broadcasts direct to limited areas only-for example, to the outlying fringe areas which are not now readily reached by local, ground-based stations and which might also be uneconomic to serve by wire. ${ }^{37}$ In this case, satellite-to-home service would be tied in with parts of the current broadcast structure (local stations

88 (1967). But see cautionary note and qualifying evidence in Herman W. LAND Associates, supra note 22 , chs. $x, 3,5$.

${ }^{86}$ Indicative of the constraints imposed by higher spectral regions are preliminary cost estimates in Comanunications Satellite Corporation, Sateldite Broadcasting-A Preliminary Report on Technical and Economic Aspects 55-65 (rev. ed. July r967).

${ }^{87}$ See Johnson, The Impact of Communications Satellites on the Television Industry, at 17 (RAND Corp. Memorandum P-3572, Apr. 1967). 
might continue), or with the proposed CATV grid, or with wired-city television. Another conception would gear the direct satellite broadcasts to contours identical with those that local ground-based broadcasters now serve. ${ }^{38}$ In either case, the commitment to local service could to some extent be honored.

But such an eventuality clearly underscores the aforementioned need to sustain the hardware and research capabilities for developing the systems in question. Insofar as direct broadcast satellites may operate to jeopardize the ground-based broadcast system and its present interconnecting links, the firms best suited to the task would, once again, presumably be those without heavy investments in the current broadcast structure.

\section{E. Diversity and Broadcast Structure}

Any regulatory program which purports to utilize pay-TV, CATV, public television, and satellites to alter the current broadcast system and FCC regulatory practice must consider also the policies most conducive to technological change. The rest of this paper will consider one such policy. It bears on vertical broadcast structure, with special reference to the proposed ABC-ITT merger and its potential impact on new communications technologies and hence on the character and effectiveness of competition. A second policy, mentioned only in passing, pertains to the inviolability of economic rents as a source of long-run support for public service programming. Clarification is badly needed here, too, lest procompetitive developments in commercial broadcasting be curbed for the sake of husbanding resources for a program service that could in fact be otherwise financed.

\section{II}

\section{Vertical Broadcast Structure, New Technology, and the ABC-ITT Merger}

Vertical ties in communications structure are by no means entirely new as evidenced by the longstanding problems posed by network-affiliate relations and the joinder of movie producers and TV stations. But their current ramifications transcend anything so far encountered. Without exaggerating the significance of any single episode, moreover, a general policy on vertical relations must clearly figure in any program to widen viewer choice through new technology. The detailed record which the FCC was virtually forced to compile in the case of ABC-ITT provides a valuable opportunity to examine the issues involved.

In petitioning the FCC to reopen its hasty approval of the proposed merger of $A B C$ and ITT, ${ }^{39}$ the Justice Department raised five points in particular. But

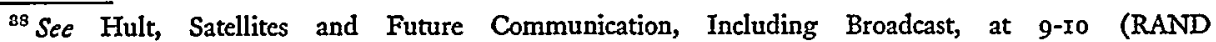
Corp. Memorandum P-3477, Apr. I967).

${ }^{30}$ Application of the Department of Justice for Stay, Application by American Broadcasting Cos. (F.C.C., filed Jan. I8, I967) [this proceeding will be cited as No. I6828 for all documents filed pursuant to it]; Petition of the Department of Justice for Reconsideration and for Leave to Intervene, No. I6828 (filed Jan. I8, I967) [hereinafter cited as Petition for Reconsideration]. The Department sub-
} 
for her acquisition of $A B C$, ITT might have (a) entered television directly by buying or building a set of TV stations and/or entering into network television afresh from that base; $(b)$ invested more heavily and promptly in CATV systems, pay-TV, and possibly in developing a nationwide interconnected CATV grid; or (c) developed still newer technologies that could further dilute network power (TV satellites for program relay or even for direct broadcasting). But for her joinder with ITT, (d) ABC might have continued to play an independent role as gadfly in a formative stage of telecommunications structure. ${ }^{40}$ Here a merger could conceivably retard the diffusion of satellite economies in lower interconnection charges and the entry of new TV networks or the growth of public television. But for the joinder, finally, $(e)$ IT'T and its suppliers would remain freer to buy advertising on any or all existing networks (or new ones) and less constrained to patronize $A B C$ in return for reciprocal favors for ITT or continued ITT orders for its suppliers. ${ }^{41}$

Without trying to examine each contention definitively, we shall focus first on ITT's potential contributions to new communications technologies competitive with the current broadcast structure, and turn next to $A B C$ as an independent factor in regulatory proceedings-with special reference to satellite organization, interconnection costs, and new network entry. Then we shall proceed, finally, to ITT as a potential entrant into network broadcasting and to ABC's attempts to bolster her competitive position therein. In short, we shall scrutinize the merger's probable effects, first, on technological factors which might otherwise transform the current economic-regulatory framework, and, second, on the character of internetwork competition within that framework. ${ }^{42}$

\section{A. ITT as a Potential Entrant into CATV and Pay-Television}

As noted earlier, CATV systems may eventually bring as many as twenty options from distant urban markets into sparse rural areas with few, if any, broadcast stations. Full network service, or even distinctive local service, can be relayed this way, providing at least the physical basis for a more varied pro-

sequently appealed the Commission's original and supplemental decisions in said docket (issued Dec. 2r, I966, and June 22, I967) to the United States Court of Appeals.

${ }^{30}$ The Justice Department referred to the joinder's effects on "the positions $A B C$ might advocate before the Commission or other public forums." Petition for Reconsideration, supra note 39, at 10. But the point is spelled out further in Applications by American Broadcasting Cos. (Memorandum Opinion and Order), 7 F.C.C.2d 245, at $3 \mathrm{IX}^{\mathrm{X}-\mathrm{I2}}$ (I966) (Commissioner Johnson's revised dissenting opinion) [hereinafter cited as Johnson Opinion]. At issue was the fear of stifling ABC's past initiatives in pressing for direct access to Comsat, for private domestic satellites, and so forth.

"11 On this last point, see Specification of Issues by the Justice Department, at 16-x8, No. 16828 (filed Feb. 15, 1967) [hereinafter cited as Justice Dep't Specifications]; Johnson Opinion, supra note 40, at 330-II.

42 The further bearing of these issues on freedom of communication was specified in the Petition for Reconsideration and Leave to Intervene of the American Civil Libertics Union, at 5-6, No. 16828 (filed Feb. 2, 1967). See also Johnson Opinion, supra note 40, at 293-304; Dissent of Commissioncr Johnson at 73-86, Application of American Broadcasting Cos. (Opinion and Order on Petition for Reconsideration) ( 1967$)$ (mimeo.). 
gramming for TV homes currently dependent on a single station or network. A microwave- (or satellite-) interconnected nationwide CATV grid, based on the individual systems now operating, could theoretically go even further in widening viewer choice. Viewers could choose explicitly between local and national service. Combined with pay-TV arrangements, a CATV wire grid might facilitate a range of options more responsive to consumer wants, including minority interests in controversial matters. The traditional problem posed by cross media and multiple ownership might then recede, on these counts at least.

Accordingly, ITT's potential role in CATV and pay-TV merited careful consideration. Aside from a $\$ 7$ million investment to construct six CATV systems in 1965 , the $\$$ ro million sum budgeted at that time, and the projected investment of another \$ro million by June I966, ITT proposed a CATV system to the New York City Board of Estimate in 1965 and explored the possibility of acquiring pay-TV interests as well. ${ }^{43}$ Furthermore, the company considered buying "at least twenty CATV systems worth ... \$I03 million." Its interest, moreover, "extended beyond CATV to the possibility of pay-TV and theatre-TV" and, more importantly, to "the possibility of creating a network linking whole areas of local CATV franchises and possibly further marketing of the services of the group," using its position as an "interconnecting communications carrier." 44 More generally, ITT viewed CATV as a growing and profitable field to enter, one noncyclical in character and closely related to the firm's basic communications activities. In addition, CATV would provide a market for ITT's finance, service, and manufacturing subsidiaries.

Such developments would have constituted significant alternatives to existing broadcast television. ${ }^{45}$ Although ITT may have chosen not to enter those fields, ABC's opposition to CATV and pay-TV was well-known. ${ }^{\mathbf{4 6}}$ Therefore, this potential conflict of interest merited closer scrutiny. ${ }^{47}$ So, too, did the applicants' assertion that there were were "many" other firms "comparable" to IT'T as potential entrants into CATV and pay-TV.

Applicants' rebuttal was actually threefold:

(I) that the FCC had deliberately restrained CATV's potential competitive role; that therefore, the potential entry of ITT was "irrelevant" since it could not develop any truly competitive CATV alternative short of some drastic change

\footnotetext{
${ }^{43}$ Letter from Donald F. Turner to Rosel H. Hyde, at 2, Dec. 20, 1966 [hereinafter cited as TurnerHyde Letter]; Justice Dep't Specifications, supra note 4x, at 8; Petition for Reconsideration, supra note 39, at $7-8$.

"Justice Dep't Specifications, sttpra note 4I, at 8-9; Proposed Findings of Fact by Justice Department, paras. 2.8, 2.1I-.12, 2.23, 2.28, No. 16828 (filed May 22, I967) [hereinafter cited as Justice Dep't Proposed Findings].

${ }^{25}$ Justice Dep't Proposed Findings, supra note 44, para. 2.30.

10 Id. paras. 2.27, 2.29, 2.3I-.33; Proposed Findings of Fact by Broadcast Bureau of the FCC, paras. 37-38, 53, No. I6828 (filed May 22, 1967) [hereinafter cited as Broadcast Bureau Proposed Findings].

${ }^{47}$ Department of Justice Reply to Opposition by ABC-ITT, at 7-9, No. 16828 (filed Jan. 30, 1967); Justice Dep't Specifications, supra note 4I, at 9-I0; Department of Justice Rebuttal to Response by Applicants, at $4-5$, No. 16828 (filed Feb. 28, 1967) [hereinafter cited as Justice Dep't Rebuttal].
} 
in the Commission's restrictive policy;" that it was at best "unreasonable" to deny the merger on one hand but then require ITT to induce the Commission to alter this restrictive CATV policy. ${ }^{49}$

(2) that these regulatory constraints, and especially the limitations in the top markets, the uncertain copyright situation, and ITT's general unfamiliarity with TV, explained its reluctance to proceed; that such uncertainties alone would make any further investment in CATV unlikely, wholly aside from the merger question. ${ }^{50}$

(3) that many other experienced, affuent CATV firms and potential entrants existed so that even if the merger did eliminate ITT, the quantitative impact on competition would still be small. ${ }^{.1}$

Without prejudging the issue two points can be made. There is no question about ITT's compelling desire to enter the domestic communications business, lucrative as this potentially looked. But the company's status as an international record carrier precluded any direct role in domestic ground station or satellite ownership, except as a Comsat stockholder (in the event of a Comsat system) or with the advent of dual-purpose earth stations. ITT's "image" as a largely foreign-based company might handicap it still more..$^{52}$

IT'T's problem, then, was how to enter this attractive communications market notwithstanding such hurdles. Aside from the $A B C$ merger, the main alternative to buying or building a group of TV stations (and perhaps to developing a network from that base) would have been to invest in pay-TV or CATV, deriving advantages therefrom in maneuvering for a preferred status in the domestic hardware market. ${ }^{53}$ In addition to sharing CATV's rising subscriber income, ITT might

\footnotetext{
${ }^{48}$ Opposition by Applicants to Petition for Reconsideration, at 59-62, No. 16828 (filed Jan. 26, I967) [hereinafter cited as Applicants' Opposition]; Proposed Findings of Fact by Applicants, para. 8.2I, No. 16828 (filed May 22, 1967) [hereinafter cited as Applicants' Proposed Findings].

${ }^{40}$ Applicants' Opposition, supra note 48, at 65-66.

${ }^{60}$ Id. at 62-63; Response by Applicants to Department of Justice Specifications, at 12, No, 16828 (filed Feb. 23, 1967) [hereinafter cited as Response to Specifications]; Applicants' Proposed Findings, stpra note 48 , paras. 8.8, 8.II-.I2.

${ }^{6}$ Applicants' Opposition, stupra note 48, at 64-65; Response to Specifications, stipra note 50, at ${ }_{33}$; Applicants' Proposed Findings, stupra note 48, para. 8.20; Reply of Applicants to Findings of Broadcast Bureau and Department of Justice, paras. 6.II-.I2, No. I6828 (filed May 29, I967) [hereinafter cited as Applicants' Reply].

${ }^{52}$ Prior to its merger with ABC, $60 \%$ of ITT's net income was derived from its foreign subsidiaries in at least forty different countries. ITT Proxy Statement of Mar. 25, 1966, at 20, No. 16828 (filed Mar. $3 \mathrm{I}$, I966). Aside from the company's image as a foreign-based hardware-telecommunication entity, heavily dependent on electronic-telecommunications equipment sales to foreign governments, at least $40 \%$ of ITT's domestic net income, and possibly more, was earned from space and defense contracts with the U.S. Government. Id. at 20; Record of Oral Hearings in ABC-ITT Merger, at 123, $147-48$, No. 16828 (conducted Sept. 19-20, 1966) [hereinafter cited as Oral Hearings]. ITT"s deliberate policy to "redress the imbalance in its income from foreign and domestic earnings" is noted in Johnson Opinion, supra note 40 , at $29 \mathrm{r}$.

${ }^{58}$ ITT's experience and capabilities in hardware manufacturing are indisputable. See Oral Hearings, supra note 52, at 5II-ז3, 519-20; ITT Proxy Statement, supra note 52; Justice Dep't Specifications, stipra note 4I, proposed testimony by Joseph V. Charyk (app. B, at 2-4) and Albert G. Hill (app. B,
} 
thereby enjoy handsome sales, especially should it one day figure in an interconnecting CATV-pay-TV grid. ${ }^{54}$ Few of the many existing CATV firms had resources or expertise comparable to ITT's for that purpose.

A second point relates to the above-mentioned regulatory obstacles that blocked any vigorous CATV system. Applicants cited this as evidence that even if ITT forfeited its right to full-scale entry into CATV this would represent no real loss of new competition to broadcast television ${ }^{55}$ and contended that the $A B C$ merger could therefore not be opposed for eliminating potential entry into CATV.

Yet unless all divergent interests in Commission proceedings are clearly articulated and prosecuted vigorously, conflicting elements in the public interest standard may not be resolved in a truly balanced way. The fact that the Commission had so far chosen to restrain CATV to protect broadcast television and, in particular, UHF and local station revenues, did not mean that it would do so for all time and in all circumstances. Changing facts might call for a new and different policy.

The elimination of ITT as a vigorous factor in CATV would eliminate the influence and pressure it might otherwise exert for a periodic and far-reaching review of the Commission's then restrictive policies. The divergent positions of ABC and ITT on CATV, ${ }^{56}$ plus the likelihood that, once merged, they would no longer openly oppose each other before the Commission, might not represent Clayton Act evidence of "elimination of a vital potential competitor," but these facts clearly deserved careful review in defining the procompetitive element in the Commission's public interest standard.

\section{B. ITT as a Source of New Communications Technology}

The three major structural alternatives to the Commission's current licensingallocation safeguards of diversity and variety-CATV, pay-TV, and satellite-TVthemselves depend on new technology for their effective implementation. In addition, other technological developments that may reduce the barriers to new TV entry include UHF transmitters powerful enough to match VHF signals in quality; CATV dissemination of UHF signals; satellites to distribute TV signals for terrestrial microwave relay to local stations (at far lower costs than currently charged); satellites to broadcast directly to homes; and, as noted, a nationwide CATV grid. ${ }^{57}$ Because such innovations promise to reduce the power of television networks and stations alike, there is some question about the wisdom of allowing those hardware

\footnotetext{
at 7-8). These preponderant hardware interests and extensive expertise (in contrast to its inexperience in broadcasting) made CATV a reasonable investment once the merger door was closed.

st See especially Broadcast Bureau Proposed Findings, supra note 46, paras. 30-32, 35, 55-56.

"See Applicants' Opposition, supra note 48, at 59-62.

to See Petition of ABC for Commission Regulation of the Carriage of TV Signals by CATV Systems, at 3-8, No. I597I (F.C.C., filed Oct. I6, I964); $c$. ITT position as documented in Justice Dep't Specifications, supra note $4 \mathrm{I}$, at 8-9.

67 Turner-Hyde Letter, supra note 43 , at 3-4. See generally pp. 462-64 supra.
} 
entities most likely to develop them to acquire substantial broadcast investments at this juncture.

One such entity-RCA-is already associated with a major television network. Others like General Electric, Westinghouse, and Philco own a number of broadcast stations. But there was a great difference between proposing to untie existing bonds and preventing new bonds (between $A B C$ and ITT), especially insofar as CBS might then feel compelled to follow suit.

At the time it sought to acquire $A B C$, ITT ranked among Comsat's five major hardware contractors, held ten per cent of Comsat stock (second after AT\&T), shared in the ownership of three initial ground stations, held some $\$ 7$ million investment in six CATV stations, and spent some $\$ 25$ million annually on research related to broadcasting (from a total $R \& D$ budget of $\$ 220$ million). It was also engaged in work abroad on improved UHF transmission techniques.

As such, ITT seemed eminently qualified as one of a small number of firms able to play a dynamic role in developing technology competitive with the current broadcast system. ${ }^{58}$ Such alternatives would not only reduce the current power of TV networks and stations but would also provide new safeguards of program diversity in their own right-more fundamental in some ways than the limits then (and still) imposed on cross-channel or multiple-station ownership. The question was simply whether ITT's half billion dollar investment in current advertiser-supported TV networking would leave it as motivated as otherwise to play its potential role in this broad and vital range of hardware development.

Applicants, to be sure, rejected any likelihood that ITT would retard the aforementioned innovations merely to protect its $A B C$ investment. ticipate in [the communications] market, it must keep pace with its competitors." ${ }^{\prime 00}$ Furthermore the restrictive regulations that govern many of these developments were said to preclude any such investment by ITT or other firms even if they so desired. And $A B C$ was deemed likely to benefit from a hardware tie as much as NBC had benefited from RCA's technical knowhow (for example, in color TV), one pertinent example being ITT's "declared interest in the advancement of UHF technology." ${ }^{11}$ ITT could also provide special technical support for satellite-to-home transmission, global TV, and space technology generally. Nor in view of the general availability of this technical know-how to rival firms could it readily afford

${ }^{58}$ Justice Dep't Specifications, supra note $4 \mathrm{I}$, at 12 \& app. B, at 2-4, 7-8, I4-I6; Justice Dep't Rebuttal, stupra note 47, at 5; Justice Dep't Proposed Findings, stupra note 44, paras. 3.1-.4; Proposed Conclusions and Brief by Department of Justice, at 3I-33, No. I6828 (filed May 29, 1967) [hereinafter cited as Justice Dep't Conclusions].

${ }^{59}$ Applicants' Opposition, supra note 48, at 68-69; Applicants' Proposed Findings, supra note 48, paras. 9.I-.5; Response to Specifications, supra note 50, at $\times 7-20$.

00 Applicants' Opposition, supra note 48, at 69.

ox Id. Applicants cited ABC's interest in UHF as a means to wider viewer access, its requests for ITT technical assistance on same, and ITT's current work on UHF technology notwithstanding poor markct outlook. Applicants' Reply, supra note 5I, paras. 7-3-.6. 
not to pursue such developments. ${ }^{62}$ Finally, ABC's continued interest in reduced transmission costs, as illustrated by its active role in domestic satellites (even after the proposed merger), was said to belie any alleged conflict of interest with ITT.

Lost from view, however, was ITT's aforementioned desire to enter the domestic communications business somehow-underscored by its cited handicap as the foreign-based parent of an international record carrier. The $A B C$ tie would at least strengthen its position in the American hardware market, and also provide insurance against any future Commission decision to authorize private nongovernmental satellites operated, say, by one or more TV networks. As a hardwarecarrier entity with a TV network subsidiary (comparable to RCA), ITT would have privileged access to the Board of any such TV network satellite system, whether organized as a joint network venture or by $\mathrm{ABC}$ alone.

What economic consequences would follow? The independent hardware supplier without TV network (let alone common carrier) ties might find it harder to place orders with a private domestic system, as some observers say it now does with the Comsat-managed global system. Any comparable joinder involving CBS would further exacerbate the independent's predicament. At the very least, new pressures would be placed on the Commission's sorely taxed hardware procurement procedures and safeguards.

On the other hand, a communications carrier with TV interests would be more likely to safeguard those interests by forestalling new developments competitive with broadcast television. ${ }^{63}$ This it could do either as a stockholder represented on the Comsat Board; as a co-owner of (dual-purpose) domestic earth stations; or as parent of a TV network subsidiary planning to establish a satellite link. Hardware competition might still induce ITT to "keep pace" in developing procompetitive wire or radio technologies. But such competition would be far less potent if IT'T had privileged access to the domestic hardware market and a powerful position therein. ${ }^{64}$

Where each TV network is owned by a large communications hardware-carrier entity, then, and where the decline of these networks would therefore operate to reduce the parents' income from hardware sales as well as from satellite circuitry, one might indeed find parents less willing to promote new technology vigorously. The favored position of such joint enterprises in selling hardware to their own domestic TV satellite system would further enable them to prevent independent hardware suppliers from entering the market, once more insulating them from outside competition. ${ }^{65}$ ITT's current and potential role in UHF technology had

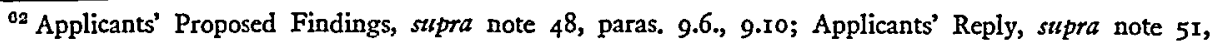
para. $7 \cdot 3$.

${ }^{3}$ Justice Dep't Conclusions, supra note 58, at 33-35.

of Id. at $35-36$.

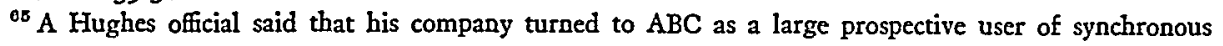


been cited in favor of the ABC merger, dependent as that network was on UHF affiliates, but ITT would hardly prosecute vigorously any UHF development that might culminate in new network entry and greater competition for its half-billion dollar investment in $A B C .^{66}$ The short-run benefits $A B C$ might enjoy from increased UHF audiences would only be offset by a truly significant growth of competition therein.

So much, then, for the merger as a deterrent to ITT's potential contribution to communications technologies which could radically transform the present broadcast structure. On three additional counts the merger might have influenced the range of program choice that emerges within the current economic-technical framework. First, it could affect ABC's independent role in regulatory proceedings, including that company's determination to bargain down the level of TV interconnection rates. The merger might thereby have affected the chances for new network entry. Second, it could have dampened IT'T's potential willingness to enter TV independently, at the station level at least, and thus to provide the ultimate basis for a new national network. On the other hand, the merger could, thirdly, so have bolstered ABC's resources as to compensate for the aforementioned anticompetitive dangers, by equalizing its competitive position vis-à-vis CBS and NBC.

In regard to competition within the current broadcast structure, then, the question is simply which group of forces will prevail. Let us consider each briefly.

\section{C. $\mathrm{ABC}$ as an Independent Factor in Regulatory Proceedings}

Because new station and new network entry can help increase the number of program sources and (under certain conditions) widen the resulting range of program choice, any factor in the present regulatory framework that operates to reduce entry barriers by reducing the cost of long-distance communication should normally be nurtured, not subverted.

Potential entrants into network broadcasting may be deterred by excessive transmission rates and equipment costs as well as by regulatory constraints. Both sets of factors are in turn affected by the vertical integration of broadcasting, communications carriers, and hardware manufacturers. According to the Justice Department, "networks not integrated with such firms are more likely to bargain down

satellite technology when Comsat had failed to express an interest-although Hughes would never have approached $A B C$ had it been associated with ITT-and that in fact Hughes turned to the Ford Foundation when "the increasing likelihood of merger between $A B C$ and ITT had a retarding effect upon [their] working relationship [with] ABC." Justice Dep't Specifications, supra note 4r, app. B, at 17-18. The prime factor governing ITT's probable future contribution to communications technology, on the other hand, was the merger's objective impact on market structure, not ITT's statements of sub. jective intent. Justice Dep't Conclusions, supra note 58, at 36-39.

${ }^{\circ B}$ A TV network's hardware parent might well stop short of innovations that so reduced transmission costs as to facilitate new network entry. An independent hardware supplier has no such inhibitions. See Johnson Opinion, stpra note 40, at 311-12; Justice Dep't Conclusions, supra note 58, at 33-35, 95-98; Justice Dep't Proposed Findings, supra note 44, paras. 3.4-.9. 
the price of communications services or equipment, and to urge regulatory policies which would tend to reduce costs and thereby to lower barriers to new entry into networking."

Not only had such companies taken divergent positions in many regulatory proceedings but ABC and I'T'T were themselves well aware of these conflicts of interest and determined to prevent them. ${ }^{68}$ Hence the possible subordination of the interests of subsidiary to parent in areas that could affect competition in broadcasting. The fact that ITT had never engaged in such practices did not mean it might not act otherwise in the future.

On the other hand, applicants contended that the Commission had fully considered the merger's structural implications; that the major change would be a desirable competitive strengthening of $A B C$ in the $T V$ network structure; that ABC-ITT would also gain an improved bargaining stance vis-à-vis AT\&T for domestic interconnection and in the international field; ${ }^{69}$ that the Commission can rightly consider consensual assurances of good behavior (and independent autonomous conduct) as well as (or in lieu of) the structural remedy of divestiture-as even Justice had reputedly done on occasion; ${ }^{70}$ and that there was no evidence anyway that ITT would impose a uniform position on its subsidiaries in regulatory proceedings. ${ }^{71}$

Of special interest here are three related issues to which we now turn: (I) the magnitude of the potential savings which satellites offer to the users and suppliers of long-distance communications; (2) the degree to which common carriers and large private users normally have taken divergent positions in the regulatory proceedings that still shape an emerging telecommunications structure; and (3) the degree to which the FCC's resultant policies will facilitate or impede Comsat's competitive impact on the international common carriers or, likewise, the potential role of private domestic satellites as competitors of conventional domestic facilities. ${ }^{\mathbf{7 2}}$

Stated otherwise, are the TV networks more likely to play a maverick role in pressing for "authorized user" status to buy direct from Comsat (and not through carrier intermediaries) when independently owned? Are they more likely in that case also to support private domestic systems in the face of common carrier opposition? How large would the potential cost savings be anyway? The competitive consequences of vertical broadcast mergers cannot really be evaluated without examining such matters at least briefly.

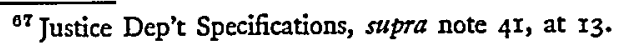

${ }^{\circ}$ Id. at I4-I5.

${ }^{\circ 0}$ Applicants' Opposition, supra note 48 , at $72-73$.

${ }^{70} \mathrm{Id}$. at $73-75$.

71 Response to Specifications, stupra note 50, at 24-25.

22 The remainder of this section is based on, and fully documented in, testimony of H. Levin, Carrier and Noncarrier Interests in Satellite Organizational Structure, Department of Justice evidentiary document No. J343, No. 16828 .
} 


\section{Magnitude of Potential Cost-Savings}

The difference between the common carriers' "retail" price to the TV networks and the Comsat "wholesale" price is hard to estimate precisely. But a glimpse into the probable differential was afforded by the "thirty-circuit"73 affair a few years ago, wherein Comsat and the record carriers each made separate bids to the Defense Communications Agency for Pacific area service. The original per-circuit bids were: Comsat, \$4200; ITT Worldcom, \$ro,000; RCA Communications, \$1r,000; Western Union International, \$II,I95; and Hawaiian Telephone, \$I2,500. Subsequently, to prevail against the winning Comsat bid, RCAC offered a low bid of $\$ 4,000$, whereas WUI and ITTWC both proposed rate reductions on their composite Pacific cablesatellite circuits of some forty per cent across-the-board.

The Commission later accepted the Director of Telecommunications Management's advice that direct access to Comsat was justified only for an initial periodpending eventual assignment of the DCA contract to the carriers. But this by no means minimizes the size of these potential savings nor, alternatively, their impact on the charges for composite cable-satellite circuits. The experience also points up, finally, the key role of the continued campaign for authorized-user status by the major private users-the TV network companies-in lowering transmission costs and the importance of such costs in new TV network entry.

The potential cost-savings due to domestic TV satellites represent still another case in point. There is admittedly some controversy over whether single-purpose or multi-purpose satellites will be more economical and which would reduce TV transmission costs the most. However, it seems clear that the mere threat of private domestic systems acted to force Comsat's and AT\&'T's hands in formulating their own versions of a multi-purpose, carrier-owned domestic system with substantial savings for the TV networks, among others.

\section{The Authorized Users Inquiry ${ }^{74}$}

The role of independent TV networks in the above cases merits further review. In Authorized Users, the networks' demand for direct access to Comsat was crystal clear. Here, in one of the most important proceedings since passage of the Satellite Act in 1962 , the divergence between common carrier and private user interests could not have been more dramatic. Almost as a group, the carriers sought to preserve their status as sole authorized users. They did so not only in Authorized Users but also in opposing sole Comsat ownership of all U.S. ground stations and in urging location of the "interface" (between satellite and terrestrial facilities) near the remote earth stations rather than the traditional "gateways" (i.e., coastal cities).

By the same token, the private users took the reverse position in strong support

\footnotetext{
${ }^{78}$ Applications of ITT World Communications Inc., Western Union International, Inc., RCA Communications, Inc., Hawaiian Telephone Co., and Communications Satellite Corp., 6 F.C.C.2d 5rI (1967).

74 Authorized Entities and Authorized Users Under the Communications Satellite Act of 1962, 4 F.C.C.2d $42 \mathrm{I}$ (I966).
} 
of direct access to Comsat. This was true of data processing and newspaper interests, truckers, manufacturers, oil companies, aeronautical interests, and the General Services Administration as well as of two TV networks; NBC did not file. But the TV networks' role was of special importance in view of their dominant position as the major private users.

When the issue was finally joined, then, NBC alone among the networks and other private users refrained from filing at all. RCAC, on the other hand, joined with the carriers in opposing the private users, Comsat, and the GSA. Thus one can clearly say that the common carrier end of the RCA entity prevailed, eliminating NBC as a potential advocate of direct access for private users. Apparently the loss of business to RCAC was weighed as more important to RCA than the extra cost-savings which NBC might have derived in the international market from a contrary resolution of the issue.

One year earlier, on the question of access to Early Bird for international TV broadcasts, a similar conflict of interest arose. ${ }^{75}$ The carriers (including RCAC) filed separately for rights to rent Comsat circuits for international TV but fell out among themselves regarding how this would be done, how the limited circuitry should be shared, and over AT\&T's eligibility to enter TV at all (as a voice carrier). The carriers were in fact assigned II4 out of the 226 circuits they requested. But pending resolution of the disagreement on eligibility, the Commission temporarily authorized Comsat and the TV networks to deal direct. To avoid compromising a forthcoming decision on authorized users, the carriers then resolved their differences promptly and successfully petitioned the Commission to rescind the temporary authorization. Opposition came from Comsat, CBS, and ABC but not from NBC. Thus when RCAC was out of the picture, NBC filed with the other networks, whereas when RCAC re-entered the picture as a party to the joint carrier tariff, NBC withdrew.

In sum, the association of RCAC and NBC silenced NBC as a potent factor in pressing for direct access rights and the lower transmission costs which these rights would provide. The fact that the other networks were "available" to perform this advocacy function did not gainsay the problem posed by the probable eventual joinder of all three (or additional) networks with the communications common carriers. Nor did the "availability" of nonbroadcast interests minimize the special importance of broadcast users in regard to either the sheer technical magnitude of their spectrum requirements or their projected share of international (and domestic) circuitry.

\section{The Domestic Satellites Inquiry ${ }^{76}$}

The case of private domestic satellites works out somewhat differently. On this

\footnotetext{
${ }^{75}$ Application of Communications Satellite Corp. for Authority to Use and Operate in Orbit Over the Atlantic Ocean a Synchronous Communication Satellite 38 F.C.C. 1298 (I965).

${ }^{70}$ Establishment of Domestic Noncommon Carrier Communication Satellite Facilities by Nongovernmental Entities, 2 F.C.C.2d 668 (1966).
} 
issue the common carriers' positions have ranged from outright denial of the legality of private systems under any conditions, to opposition notwithstanding legality (on grounds of inefficiency), to opposing them at this time in the face of spectrum limitations and the need to accommodate the carriers and general users first. Although the TV networks favored the private systems, their positions also varied considerably. $A B C$ and $C B S$ have favored such systems outright, whereas NBC conditions its approval on the Commission's determining, on a case-by-case basis, the relative efficiency and spectrum requirements of private and carrier-owned systems and the speed with which either could be established.

In contrast with Authorized Users, then, NBC did file on domestic satellites, whereas RCAC did not. One might therefore conclude that the value to RCA of lower transmission costs for NBC (via a private domestic satellite) was worth more than the mere principle of favoring carrier-owned domestic systems (from which RCAC would be excluded anyway as an international carrier) and also more than the benefit to RCA's stockholdings in Comsat itself, as a potential systems owner. Beyond the value of a private system to the NBC network, moreover, and probably of greater economic significance, was the value to the RCA hardware interests of a favored position in the domestic satellite hardware market. Obviously the more numerous the satellite systems, the larger the hardware requirements and the larger the market. As the sole hardware company with a TV network (and common carrier) subsidiary, RCA would clearly stand to gain more from the authorization of private domestic systems than from its Comsat stockholdings (it has no place on the Comsat Board) or from its future sharing in domestic ground station ownership along with Comsat and the other carriers. Stated otherwise, the NBC end of the enterprise prevailed in the Domestic Satellite proceeding, just as the RCAC end prevailed throughout Authorized Users and the Early Bird deliberations. This may seem reasonable insofar as RCAC is an international, not a domestic entity, and hence not legally qualified to operate in the domestic satellite market, but ITTWC and WUI, subject to identical constraints, both entered the domestic proceeding as proponents of multi-purpose, carrier-operated systems and in opposition to private special-purpose ones.

It is hard to state categorically what difference for policy formulation may result when one end of a joint enterprise speaks for the whole enterprise in proceedings where both ends might appear on different sides were they independent. However, anything that narrows the Commission's range of choice among competing options must be suspect at this formative stage of satellite organization.

As a matter of principle, it seems hard for any international carrier that strongly opposes the private users in their campaign for direct access to Comsat in the international market to condone it domestically or to give blanket endorsement to private domestic systems (the more probable domestic equivalent). For that reason alone it is understandable that ITTWC should give only limited qualified approval 
of private systems "in the future," and that RCAC should remain silent (especially in view of NBC's role). But a closer look at the RCAC, NBC, and ITTWC positions reveals them as strategies at least consistent with the hardware interests of their parents.

By leaving the door open to a future TV network joint venture buying its satellite service from AT\&T and Comsat, or otherwise, e.g., NBC compromised between any unqualified endorsement of independent private TV satellite systems unrelated to Comsat and the other carriers (ABC, CBS), blanket opposition to such systems (Comsat, GT\&E, Western Union Telegraph), or opposition to private systems "for the foreseeable future" (AT\&T, ITTWC). This spared RCAC the dilemma of being the sole carrier on record to condone a private TV satellite system now, or of having to oppose it publicly (against $A B C, C B S$, and others).

Independent $A B C$ and ITT behaved quite differently in the same proceedings. One wonders whether their divergent positions would have continued very long in the event of a joinder: the record on RCA and NBC suggests otherwise.

\section{ITT as a Potential Entrant into TV Broadcasting}

New network entry or the emergence of specialized network groupings short of full-fledged national networks would be welcome additions to the structural safeguards of program diversity described earlier. The question, however, was not whether ITT would have entered TV networking directly had the merger route been closed but whether it might at least have acquired a group of TV stations (or built its own in the UHF), thereby gaining the experience and investments which could later induce it to move in that direction.

Large-scale programming economies and strategic advantages derived from the network-affiliate relation, or from earlier radio investments, were not the only barriers to new TV network entry. Technical factors were also known to restrict new station entry (and thus new network entry). Only a handful of markets had four or more VHF outlets allocated and/or on the air, and there were few UHFonly markets (in which new UHF stations could effectively compete). Yet tradition has it that a new network must gain access to the top fifty or 100 markets almost entirely on its own affiliated stations. New network entry would therefore seem far more likely when the UHF band develops and, with it, the number of multi-station markets with four or more stations.

What bearing did such conditions have on the proposed merger? We know that ITT had considered entering the domestic television business during the two preceding years but ceased such explorations once the merger with $A B C$ seemed likely. ${ }^{77}$ ITT explored the possibility of buying a number of TV groups (Storer, Corinthian, Travelers, Gross) or some individual stations, and also considered building its own

\footnotetext{
${ }^{77}$ Justice Dep't Proposed Findings, supra note 44, paras. I.I, I.26; Justice Dep't Conclusions, supra note 58, at $14-16$.
} 
(in the UHF). ${ }^{78}$. However, ITT rated these alternatives as less attractive than acquiring a TV network outright-its first choice being CBS. ${ }^{79}$ Efforts to acquire a group of television stations stopped after the merger with $A B C$ was deemed possible. Yet the purchase of group-owned stations would have represented an alternative basis for possible future entry into networking. ${ }^{80}$

To be sure, ITT at no time explicitly indicated an intent to follow that route. ${ }^{81}$ Indeed it lacked the necessary experience with programming, advertising sales, radioTV operations, and affiliation arrangements. The shortage of VHF outlets had theretofore deterred new network entry by affluent and far more experienced TV group owners-potential entrants closer to network television than ITT (even should the UHF situation improve) ${ }^{82}$ Applicants concluded from this that preventing the merger would in no way guarantee ITT's entry and therefore had no antitrust significance. The merging company had the financial resources, they conceded, but lacked the technical ability and commercial experience needed to enter the network television market. It was neither anxious nor eager to enter, nor recognized by other firms as a likely entrant, and was by no means among " $\mathrm{a}$ few firms posing a realistic threat of entry."

Nonetheless, ITT did have good general reasons to enter TV broadcasting as a profitable field "whose growth (was) not limited to any narrow product line," and whose revenues showed "a noncyclical growth pattern." Here was a chance to generate surplus capital in an industry marked by entry control without rate control as well as by low capital requirements. As also noted earlier, a large investment in television would help ITT increase the portion of her earnings earned domestically.

Aside from the uncertainty of ITT's entry into full-blown networking, what about the further possibility of its more modest entry as a group owner pure and simple, and of its building out from there to develop some limited specialized network capability? Some TV group owners had considered eventual entry into networking based on their station operations. Part-time or specialized network groupings included the Sports Network and a Sunday afternoon venture organized some years ago by Patrick Weaver. Beyond this, the United Network had tried (unsuccessfully) to launch full-scale operations entirely in the UHF band from a nucleus of its own stations. ${ }^{84}$ National Educational Television also serviced a non-

\footnotetext{
${ }^{78}$ Justice Dep't Proposed Findings, sttpra note 44, paras. 1.20-.23, 1.25.

${ }^{70}$ Id. paras. $1.20-.23,1.25$.

${ }^{80}$ See Turner-Hyde Letter, supra note 43 , at 2; Petition for Reconsideration, supra note 39 , at 7. Details are itemized in Justice Dep't Specifications, stipra note 41, at 5-7. See also Letter from Donald F. Turner to Herbert F. Bergson, at 3-4, Jan. 24, r967. The contents are reviewed with attcmpted rebuttal in Applicants' Opposition, stupra note 48, at 52-57; Response to Specifications, stura note 50, at 8-ro.

${ }^{81}$ Applicants' Opposition, supra note 48 , at 52-54; Response to Specifications, supra note 50, at 8-10; Applicants' Proposed Findings, stupra note 48 , paras. 7.8-.II.

${ }^{89}$ Applicants' Opposition, stupra note 48, at 54-56; Applicants' Proposed Findings, stipra note 48, paras. 7.9-.I0; Applicants' Reply, stupra note 5x, para. 5.8.

${ }^{83}$ Applicants' Opposition, supra note 48 , at 50.

8s The Overmeyer Network was reorganized and renamed the United Network at that time. Over-
} 
profit educational network including many UHF stations, and there was talk of a more extensive educational service. As a stronger group owner than many, ITT might have been willing to proceed where others had not (once it had gained the needed experience and the UHF spectrum had come of age).$^{85}$

True, likely potential network entrants with substantial capabilities and interestsfor example, Metromedia, RKO General, and Westinghouse-had taken no such steps to date. But ITT was much larger than the first two companies, and, unlike Westinghouse, would initially have owned independent stations in the major markets. ${ }^{86}$ Any company so situated would presumably have good reason to generate its own programming (to build audience circulation), and then to spread the programming costs over a large number of affiliated stations. ${ }^{87}$ Moreover, a strong network service would surely have enhanced the value of any owned and operated stations.

\section{E. ABC's Competitive Position in Network Television}

A merger with $A B C$, then, could have blunted IT'T's potential role in pay-TV, CATV, or in later creating a new television network. But would the merger have bolstered ABC's competitive position as a national network? And, if so, would this have compensated for any impairment of $\mathrm{ABC}$ 's independent role in regulatory proceedings along lines reviewed earlier?

In first approving the merger in December Ig66, the FCC cited ABC's urgent need for capital not otherwise available to facilitate speedy conversion to color, studio expansion, and the enlargement of news and public affairs programming. ${ }^{88}$ Cited also was the bolstering effect on UHF television. ${ }^{89}$ The Commission majority subsequently cited ABC's declining share of a growing network revenue pie, and its actual losses in TV networking, as evidence of a deteriorating competitive position. ${ }^{90}$ The company further attributed such "deterioration" to deficient audience coverage over its UHF affiliates and to a relative inferiority in winning primary affiliates in one- and two-station markets. ${ }^{01}$ Cited finally were ITT's financial resources as

meyer remained the largest single stockholder, and Treyz the president, but equity was added by new stockholders, three of whom also hold major stock in the Mutual Radio Network. Broadcasting, Mar. 13, 1967 , at $23-26$.

${ }^{86}$ ITT cited its own lack of experience in programming, entertainment, world-wide news gathering, time sales, etc. Applicants' Opposition, supra note 48 , at 53-56. But, in buying a group of television stations, it clearly bought some of the above capabilities, too, as well as the chance to gain needed experience.

Ba Justice Dep't Conclusions, supra note $5^{8}$, at 20-22.

${ }^{87}$ Justice Dep't Proposed Findings, stupra note 44, para. I.27.

${ }^{88}$ Application by American Broadcasting Cos. (Memorandum Opinion and Order), 7 F.C.C.2d 245, paras. $23-24,28$ (1966) [hereinafter cited as ABC-ITT Original Opinion].

${ }^{80}$ Id. para. 29 .

${ }^{0}$ Applications by American Broadcasting Cos. (Opinion and Order on Petition for Reconsideration), 9 F.C.C.2d 546, paras. 59-60 ( 1967 ) [hereinafter cited as ABC-ITT Reconsideration Opinion].

${ }^{91}$ Applicants' Proposed Findings, supra note 48, paras. 2.I6-.25, 2.29-.35, 2.43-.45; Applicants' Reply, supra note $5 \mathrm{I}$, paras. $2.1-.6,2.16$. It is hard to allocate the relative portion of revenue deficiency 
crucial to underwriting the risky program innovations needed to overcome these deficiencies. ${ }^{22}$

Yet there was evidence of competitive strength in the growing absolute level of $A B C$ 's network revenues, the over-all profitability of its network-plus-station operations, and its thirty-one per cent share of combined prime-time network revenues. Pertinent also was the full comparability of $A B C$ 's prime-time program ratings with those of CBS and NBC. ABC's best programming could (and did) win more prime-time clearances from its secondary affiliates than the less popular CBS and NBC shows sometimes won from their primary affliates. ${ }^{93}$ Finally, diversity of size may itself precipitate (not impede) innovation and competition, as is well illustrated by $A B C$ 's aggressive rate policy, its initiation of so-called "counter-programming" in prime-time, and its early proposal for a special-purpose domestic satellite for TV interconnection..$^{94}$

In effect, $A B C$ had fewer primary affiliates than $C B S$ and NBC, there being thirty-six two-channel markets where it could deal with secondary affiliates only. Yet $A B C$ had sometimes won primary affiliates in such markets, as well as choice program clearances over its secondary affiliates. ${ }^{95}$ While delayed programming at an inconvenient hour might result in smaller audiences than live clearances would, and would also require costly film prints, such programming could do better, depending on competition and the popularity of preceding lead-in programs, than that of the competition.

The fact is that $A B C$ 's more popular programs had won ratings in over-all prime-time programming that far exceeded those associated with its primary affiliates alone. The key, then, was attractive programming, and for $\mathrm{ABC}$ to match its popular prime-time service with comparable daytime offerings. ${ }^{06}$ This might even assist it to win more primary affiliates in the one- and two-station markets. The chances to compete openly for program clearances in all markets would be further facilitated by the weakening of historic ties and loyatlies between all networks and their affiliates. (Network shows are now rejected with greater frequency by affiliated stations, which choose their programs solely on the basis of popularity.)

To strengthen its position vis-à-vis $C B S$ and NBC, finally, $A B C$ initially convinced the FCC that it had to make capital outlays of \$I 40 million for color con-

as between deficient programming and deficient coverage. But applicants emphasized their inferiority in primary affiliates and clearances, citing their lower program ratings in Nielsen's Thirty Market Survey, where they did have comparable competitive primary affiliates. Id. para. 2.1\%.

${ }^{02}$ Applicants' Proposed Findings, stlpra note 48, paras. 6.2-.9; Applicants' Reply, stupra note 51, paras. 2.8-.II.

${ }^{83}$ Justice Dep't Conclusions, stupra note 58, at 83-84; Justice Dep't Proposed Findings, sutpra note 44, paras. 6.8-.I0, 6.13-..8.

${ }^{84}$ Justice Dep't Proposed Findings, supra note 44, para. 6.9; Justice Dep't Conclusions, supra note 58 , at $85-86$.

${ }^{25}$ Justice Dep't Proposed Findings, supra note 44, paras. 6.11-.I5.

${ }^{90}$ Id. para. 6.I3. Some ABC primary affiliates in adjacent markets could enter and get some coverage here, too, if programming were popular, and this may offset lack of primary affliates. Furthermore, the significance of spectral location in the VHF band seems exaggerated. Id. paras. 6.20, 6.22-.23. 
version, new headquarters, and studios. ${ }^{97}$ It also claimed that large sums were needed to finance an expanded news and public affairs budget, documentaries and specials, and to counter effective bidding for film features. Money was needed more generally to cope with rising program costs and competition in a global market. ${ }^{98}$ On each count, $A B C$ justified the proposed merger with ITT along lines reminiscent of its merger with United Paramount in 1953. Yet the real question was whether other conventional means to finance these needs were now available (assuming, of course, that the needs themselves were bona fide).

Clearly, ABC contended (I) that disallowance of the merger would force a sharp reappraisal of commitments to bolster its coverage of news, public affairs, and special events; ${ }^{99}$ (2) that conventional financing would impose onerous restrictions on management in regard to working capital, limited dividend payments, additional borrowing, and long-term leases; and (3) that such restrictions would impair management's ability to sustain continued losses in the news and public affairs area, let alone to make long-term commitments for feature films. Yet the magnitude and speed of color conversion and plant expansion also helped explain the inability to finance such improvements, and the increased costs of network programming, internally. Nor did the then projected programming reveal any need for such large investments in so short a time. ${ }^{100}$ There was indeed some evidence that the whole case for colorization and plant expansion may have been formulated to justify a merger largely sought on other grounds. ${ }^{101}$

The question is whether all viable financing options had been fully explored before deciding to merge. $A B C$ had theretofore managed not only to meet its past needs out of internal cash sources but also to borrow on favorable terms (\$7o million from its main creditor, Metropolitan Life, and, with the latter's waiver of debt restrictions, $\$ 25$ million from ITT and $\$ 27,500,000$ from several banks). Nor did the fact it could incur only $\$ 5$ million more in long-term debt under Metropolitan's then effective debt ceiling preclude the possibility that Metropolitan might, as in the past, raise that ceiling.

In sum, the combined evidence on viable financial alternatives, ${ }^{102}$ and on the company's exaggerated short-run capital needs, was so persuasive that the notably "neutral" Broadcast Bureau found no significant support for a merger with ITT on either count. ${ }^{103}$ On balance, the Justice Department's showing here sufficed to induce the Commission majority to drop its earlier emphasis on financial need, venture capital, and the merger's alleged role in strengthening internetwork com-

\footnotetext{
${ }^{07}$ ABC-ITT Original Opinion, stipra note 84, para. 24.

${ }^{08}$ Id. paras. 27-28; Applicants' Reply, stupra note 5I, paras. 3.1-.3.

${ }^{\circ 0}$ Applicants' Reply, supra note 51, paras. 3.71-.76; Applicants' Proposed Findings, supra note 48, paras. $4.62,6.11-.17$.

${ }^{100}$ Justice Dep't Conclusions, supra note 58, at 89-92.

${ }^{101}$ Id. at 87-89, 102-103; Justice Dep't Proposed Findings, supra note 44, paras. 6.34.37, 6.44-.45.

${ }^{102}$ Justice Dep't Proposed Findings, supra note 44, paras. 6.92-.95, 6.98-.102, 6.103.

${ }^{103}$ Proposed Conclusions by Broadcast Bureau, paras. I4-I5, No. I6828 (filed May 29, I967).
} 
petition and program quality. ${ }^{104}$ Instead the Commission focused on the other four points which Justice claimed had been improperly ignored or discounted. ${ }^{105}$

\section{F. Implications}

All in all, a TV structure associated with communications common carriers increases the likelihood that some of the strongest pressures for direct access to Comsat, or for private satellite systems, will diminish. In that sense, such an alliance would not only modify telecommunications structure in its own right but also influence key regulatory decisions during a crucial formative stage of that structure. The competitive effects of these modifications cannot be predicted with certainty at this time. But if one views the satellite as a potential competitive alternative to cable and microwave for the large private user, then any move to forestall such competition would be undesirable.

On each of the above counts the ABC-ITT merger could have thwarted potential threats to the existing broadcast structure: first, by reducing IT'T's incentive to enter TV in some way other than by buying the ABC network and then at some subsequent point launching a full-scale network operation; second, by eliminating ITT as a potential entrant into CATV and pay-TV notwithstanding its early interest in these fields; third, by reducing the likelihood of IT'T's playing a dynamic and innovative role in new communications technologies competitive to broadcast television, including the development of such radical conceptions as a direct broadcast satellite and a nationwide CATV grid; and, fourth, by reducing ABC's role as a factor in bargaining down transmission rates and otherwise influencing satellite organization in ways that would subject the terrestrial carriers to greater competition while increasing the chances for new network entry.

On the other hand, the merger's procompetitive effects within the present TV network structure were not so demonstrably self-evident as to justify merger irrespective of the other dangers.

It follows that regulatory policy on vertical broadcast structure must take fully into account possible effects on the speedy emergence of technologies competitive to broadcasting and thus of viable new safeguards for program diversity. In analyzing the risks of blunting the incentives of procompetitive technological change, new network entry, and lower interconnection charges, the question was not merely how likely ITT (or ABC) would have been to act in any particular way but for the merger. Also to be considered was how much risk we could afford to run, in depriving ABC of ITT's venture capital, to avoid whatever anticompetitive risk the merger clearly did pose. No one denied that there was some anticompetitive risk, or that the chances for procompetitive innovation would be greater without the merger, on some counts at least.

\footnotetext{
${ }^{104}$ ABC-ITT Reconsideration Opinion, supra note 86, paras. 58, 67-69; cf. ABC-ITT Original Opinion, supra note 84 , paras. 23-24.

${ }^{105}$ ABC-ITT Reconsideration Opinion, supra note 86, paras. 9, I9, 29, 39, 48, 73-74.
} 
So much then for this passing look at vertical broadcast structure. Competition may also be obstructed by restrictive FCC policies based on invalid assumptions about the need to preserve industry wherewithal for public service programming. These have figured repeatedly in the Commission's thinking: first, in its initial reluctance to scotch admittedly restrictive network policies; then, in blocking CATV's entry into the big-city markets and in failing to promote direct broadcast satellites more promptly; and, more generally, in its long opposition to even as anemic a version of pay-TV as conceivable under the proposed new rules.

The prospects for an enlarged system of nonprofit public television offers hope that these outmoded conceptions may now be revised. Yet here, too, one sometimes encounters fears that the onrush of new technology may operate to sap likely sources of financial support for this most vital alternative of all. We could not peruse those issues here. However, the further development of terrestrial microwave relays might indeed impair satellite economies as a source of support for public television, just as the growth of CATV or wire television may reduce the present volume of broadcast rents also available for that purpose.

The fact is that satellite economies and economic rents can still properly play some role in financing public television, provided they are kept from perpetuating the Commission's traditional reluctance to accommodate to procompetitive technologies. Here a package of several tax options might best avoid this danger, while at the same time side-stepping the political hazards of selecting any single spectrum user to pay the whole bill. ${ }^{106}$

\section{Conclusion}

The major alternative to the licensing-allocation policies which the FCC now imposes on the broadcast structure is a program to promote new technologies likely to alter that structure and otherwise introduce greater incentives for program diversity. Paramount here are community antenna television, pay-television, and new network entry in broadcast television via an activated UHF band. Even more promising is a system of national educational television (public television). Each option may now figure in any program to widen viewer choice and among the ways to infuse procompetitive factors into regulatory practice.

Beyond this, a number of new technological configurations could eventually modify the present ground-based microwave- or cable-interconnected local broadcast system. These include distribution satellites for low-cost TV network interconnection,

\footnotetext{
${ }^{100}$ One likely package would mainly consist of a gross receipts tax on commercial broadcasting and a charge for access to the spectrum, with supplemental funding from satellite economies, subscriber fees, and a limited amount of advertising. See D. Netzer, Long-Range Financing of Public Broadcasting (National Citizens Committee for Broadcasting, r969). See also J. DimLIng \& G. Coffex, The Evatuation of Alternatives for the Production, Distribution and Financing of Television Programs, at $x 1-13,52-59$ (Spindletop Research, Inc., Report No. 219 for the ODTM, April I967); Reply Comments of the Ford Foundation, vol. I, at 35-47 (memorandum of J. Pechman), No. I6495 (F.C.C., filed Dec. r2, rg66).
} 
wired-city television, a nationwide CATV grid, and direct TV broadcast satellites. In each case, the new configurations may transform the current broadcast structure in ways that diversify program choice in their own right. Additionally, in most cases varying amounts of broadcast spectrum will be released to next-best users.

The development and introduction of these new technologies will require $(a)$ hardware entities with adequate incentives and capabilities, and (b) a Commission willing to accommodate rather than restrict them. On the one hand, vertical broadcast structure necessarily affects the rate at which technologies competitive with broadcasting will be introduced, and a useful case study here has been derived from the record on the abortive proposal for a merger between $A B C$ and ITT. A second constraint on procompetitive innovation, mentioned only in passing, relates to the FCC's sensitivity to developments which might impair the broadcaster's public service capabilities. If procompetitive technologies are to be innovated optimally, therefore, careful analysis (beyond our scope here) is also urgently needed to test the continued validity of the Commission's longstanding presumptions about the linkage between "industry wherewithal" and program diversity. 